\title{
Political Unrest and Educational Electronic Resource Usage in a Conflict Zone, Kashmir (Indian Administered Kashmir): Log Analysis as Politico Analytical Tool
}

\author{
Hindistan Tarafından Yönetilen Keşmir Anlaşmazlık \\ Bölgesi'nde Siyasi Karışıklık ve Eğitimle İlgili Elektronik \\ Kaynakların Kullanımı: Siyasi Analiz Aracı Olarak Log Analizleri
}

\author{
Sumeer GUL ${ }^{*}$, Samrin NABi* , Samina MUSHTAQ**, Tariq Ahmad SHAH***, \\ Suhail $A H M A D^{* * * * *}$
}

\begin{abstract}
Electronic resource usage has proved as one of the best decision making tools in the library setups. Electronic resource usage in relation to the political disturbance can act as one of the tools to highlight the impact of political disturbance on educational setups in general and the electronic resource usage in particular. The study takes a serious look in the electronic resource usage in Kashmir and the impact of unrest on it. The paper highlights a relational platform between education and conflict studies. How conflict affects the electronic resource usage in a conflict zone has been highlighted in the study. Transaction logs in the form of COUNTER Report deliberating the usage of Project Muse journal titles at University of Kashmir were analyzed to know the extent of usage of e-resources by the academia of Kashmir during the time of conflict from a time period of January 2008- December 2010. Peace has a great role to play in the development of any community from every aspect. Political disturbance hampers the educational sector to a greater extent. The usage logs helped to reveal the actual picture of academic behaviour of Kashmiris in the time of conflict. The study clearly reflects that political disturbance has a negative effect on the educational sphere in general and electronic resource usage in particular. The study was confined to the analysis of the transactions logs generated from Project Muse at University of Kashmir. The study can lay a base for the policy makers associated with education to take some immediate and curative steps that can control the devastating effects on the academia caused because of frequent disturbances in the valley of Kashmir. The study is an eye opener for the academicians and the policy makers in Kashmir. The study will be helpful in visualizing the utility of log analysis
\end{abstract}

\footnotetext{
* Assistant Professor, Department of Library and Information Science, University of Kashmir, India. (sumeersuheel@gmail.com)

** Librarian; Nund Rishi College of Education.Natipora. India. (smrnabi33@gmail.com)

** Librarian, Raihan College of Education, India. (saminakhan2010@gmail.com)

**** Research Scholar, Department of Library and Information Science, University of Kashmir, India (tariqahmadshah@gmail.com)

***** Researcher, University of Kashmir, India (ahmad7suhail@gmail.com)
} 
in reflecting the ill effects of political disturbance on academic circles. The paper is first of its kind trying to link education and conflict studies of a politically simmering area, Kashmir. The research can further be extended to analyze the impact of political normalcy on the academia of Kashmir. How normalcy acts as an indicator of enhanced e-resource usage can be studied.

Keywords: Log analysis, Electronic resource usage, Information seeking behaviour, Education policies, policy, India, Kashmir

\section{Öz}

Elektronik kaynak kullanım analizi, kütüphane hizmetlerine yönelik olarak yapılan planlamalarda en iyi karar verme araçlarından biridir. Elektronik kaynak kullanım düzeyinin belirlenmesi, ülkelerdeki siyasi karışılıklardan etkilenen eğitim planlamalarının yapılmasında önemli bir araç olarak nitelendirilebilir. Bu çalışma, Hindistan Keşmir Anlaşmazlık Bölgesi'ndeki elektronik kaynak kullanımınıve siyasikarışılıkların bu kullanım üzerindekietkisini incelemektedir. Ocak 2008 - Aralık 2010 tarihleri arasındaki anlaşmazlık döneminde Keşmir Üniversitesinde Proje Muse dergisinin makalelerinin kullanımı loglar aracılığıyla analiz edilmiştir. Barış süreci, toplumların gelişiminde her yönden büyük bir role sahiptir. Siyasi anlaşmazlık ise eğitim alanında yaşanacak gelişimin sağlanmasında büyük ölçüde engel teşkil etmektedir. Araştırmada, anlaşmazlık sürecinde Keşmirlilerin akademik davranışlarının gerçek durumu, loglar aracılığıyla ortaya konulmuştur. Araştırma, siyasi anlaşmazlığın genel olarak eğitim alanında, özel olarak elektronik kaynak kullanımında olumsuz etkiler yarattığı gerçeğini yansıtmıştır. Bu araştırma, Keşmir Anlaşmazlık Bölgesi'nde yaşanan ve eğitim alanında olumsuz etkiler yaratan siyasi anlaşmazlığın etkilerinin azaltılmasında eğitimle ilgili politikacılara fikir vermesi bakımından önemlidir. Ayrıca bu araştırma log analizlerinin, siyasi anlaşmazlığın akademik çevrelere yönelik ortaya koyduğu olumsuz etkilerin saptanmasında yardımcı olacağını vurgulamaktadır. Araştırma, Keşmir'de siyasi anlaşmazlık ve eğitim arasındaki ilişkiyi ortaya koyan ilk çalışmalardan biridir.

Keywords: Log Analizi, Elektronik kaynak kullanımı, Bilgi arama davranışı, Eğitim politikaları, Siyaset, Hindistan, Keşmir

\section{Introduction}

Kashmir, the name in itself brings a sense of heavenly feeling as many scholars have commented on it as "Paradise on Earth" (Aggarwal \& Agrawal, 1995; Jaisingh, 1998; Mohan, 2000; Inden, 2008). The beauty and serenity of Kashmir is known all over the world. The luxuriant beauty, magnificent lakes and gleaming springs add more to its charm. Situated between the snow clad mountains, Kashmir was in real sense a paradise, a beautiful and an enchanting place. But since late 80 's the valley of beauty and peace turned in to one of the disturbed places and highly militarized zone (Dehlvi, 2009; Navlakha, 2009). The nineties have seen a dramatic escalation of the conflict in Kashmir, which has become the site of a triangular struggle between India, Pakistan and a popular movement demanding independence (Bose, 1997). In fact it would be right to say that Kashmir has now turned to a hell. The experiences we witness here right from our childhood has fainted the idea of Kashmir, being a paradise on earth. The political disturbance has hindered the peace and harmony of Kashmir valley to 
a greater extent. It has become a pride game between India, Pakistan and China but more particularly between India and Pakistan. Even Roy (2011) links Kashmir's future as a democratic, inclusive and pro-secular space to what happens with India and Pakistan which clearly reflects that the political scenario of Kashmir is highly associated with the political ties between the two nations. While tensions have lingered over the last 60 years, wars between the two countries over Kashmir have been frequent but relatively short, taking place in 1948, 1965, 1971 and 1999 (Sudan, 2010) which in one or the other way had affected the peace in Kashmir. But, none of the wars reaped benefits for Kashmir. They, every time became the catalysts in destructing the peace and harmony of Kashmir. The educational system of Kashmir which was once known for all over the world has also been affected because of the political dwindling that Kashmir has been witnessing from a very long time.

Early nineties witnessed one of the biggest thrashes to the educational system in whole of the valley. Though Jammu and Ladakh are the associated divisions of the state of Jammu and Kashmir, but it is the Kashmir division that suffered most during the period of political unrest. Somehow, the political conditions turned to a soothing pace if not normal in late nineties and the starting years of the $21^{\text {st }}$ century. Yet, the educational sector had very less to witness that could have boosted it and compensated its past loss. Though Internet made its debut in Kashmir very late (late 90's) as compared to other states of India, it proved as one of the important factors in promoting the lost educational dimension in the valley. The "accessibility philosophy of Internet" replaced the "philosophy of ownership" that was highly prevalent in the traditional educational system in the valley. Things turned positive especially for educational sector and it was higher education that was highly influenced due to the debut of online scholarly communication system in the form of electronic resources. Education and research activities gained momentum as Internet brought new forms of scholarly communication models for academically alienated scholars of Kashmir. Things were working normally till the year 2007 in the educational sector when suddenly year 2008 brought the greatest devastation that shattered the valley. The political unrest which started in the year 2008 did not stop and the years 2009 and 2010 also followed the footprints of violence and disturbance which started in 2008. Politicians witness 2008 unrest as the second biggest uprising in Kashmir since 1990. The civil disobedience and political instability in Kashmir disturbed every societal element and education also witnessed a huge breakdown.

The emergence of Internet in the valley brought to the scholars of the valley the erevolution in the form of electronic information resources. Their information seeking behavior changed from the ownership platform to that of accessibility. The digital accessibility to information to a greater extent solved the problems of academia of Kashmir. But the political instability not only ruined the social, cultural and business lives of people but the educational sphere of Kashmir also witnessed a great thrash back. The cyber behaviour of researchers in Kashmir also got affected because of political disturbance. 
Log analysis, one of the tools aimed at highlighting the user behaviour in the cyber world has been used for various decision making and management policies by the librarians subscribing to or accessing the e-resources. Some authorities call log analysis the "digital fingerprints"(Nicholas, Huntington \&Watkinson, 2005) of the users while others comment on it as "CCTV of cyberbehaviour" (Nicholas, Huntington, Lievesley \& Withey, 1999). Log analysis has also been recognized as a platform to unveil the damned lies also (Udell, 1996). It has been used for exploring the users and their behaviour to fullest.

Since the field of Education and Conflict Studies is receiving increased attention, within media (Paulson \& Rappleye, 2007), in the academic field, and from policy makers and practitioners (Tomlinson \& Benefield, 2005 b) all over the globe, the present study highlights the relational aspect of political turmoil and electronic resource usage in a conflict zone, Kashmir. The study is carried out to find out the use of e - resources by the academia of Kashmir in the years of its worst political disturbance, after 1990 uprising (2008 through 2010). How the political disturbance has affected the e-resource usage at academic institutes in Kashmir has been studied extensively. The paper highlights a relational platform between education and conflict studies.

\section{Review of Related Literature}

\section{Conflict and Education}

Conflicts all over the globe have devastated humanity and the various facets associated with it. Suffering education because of conflict is clear and evident from some of the studies (Seitz, 2004 a, b; Tomlinson and Benefield, 2005 a). The Oxfam Education Report shows that $2 / 3$ of African countries affected by conflicts had enrollment rates of less than 50\% (Watkins, 2000). Furthermore, the United Nations Development Programme (UNDP) states that countries in conflict are likely to spend less on education. Wars and conflict impair the functioning of education systems and often lead to extensive damage to the original education infrastructure (Seitz, 2004 a).

Education systems should be well geared up to prevent, cope with, deal with the after effects of conflict, and generally contribute to the promotion of non-violent solutions to the wide range of inequalities that have emerged out of recent processes of globalization (Stewart, 2003; Colenso, 2005). One of the best studies carried out by UNESCO Institute for Statistics (2010) reveals the quantitative impact of conflict on education. The study examines the impact of armed conflict on the population of twenty-five countries, finding substantial negative effects of exposure to conflict on educational attainment and literacy. The study also contributes to the growing literature in this field by demonstrating the lasting impact of conflict on education for a large and diverse set of countries. 


\section{Log Analysis}

Log analysis, a term that is not new in the research world has been researched by number of authorities. A number of visualizations have been made on log analysis regarding its usage and purpose. Some authorities call it the "digital fingerprints" (Nicholas, Huntington \& Watkinson, 2005) of the users while others comment on it as "CCTV of cyberbehaviour" (Nicholas, Huntington, Lievesley \& Withey, 1999). Log analysis has also been recognized as a platform to unveil the damned lies (Udell, 1996).Commenting on the user behavior in the web world, Nicholas, Huntington, Lievesley and Withey (1999) see it as a treasure trove of data. Covey (2002) maintains that transaction log analysis (TLA) was developed about 25 years ago to evaluate system performance. He further suggests that TLA can also be used for collecting correct usage statistics and analyzing and interpreting the data. However, Peters (1993) with an extensive review of past studies visualizes that this method has been used since 1960 for different purposes.

\section{Methodology}

The study is based on log analysis to assess use levels of e-resources electronic resources in the period of highest political unrest after 1990 uprising in Kashmir. Transaction logs in the form of COUNTER Reports were mined from Project Muse's usage statistics site from the first week of January 2008, for a period of 36 months, to December 2010. In addition, various sources especially local magazines/newspapers highlighting the political disturbance in Kashmir were consulted to correlate the turbulence in Kashmir with the e-resource usage.

\section{Findings}

\section{Article View}

Table I, (Figure 1) reveals a marked monthly usage pattern of journals in three years study period. 2009 shows peak access with an average of $45.66 \%$ article views, whereas 2008 shows an average of $25.41 \%$ article views. The average access for the year 2010 is very low (1.25). The month of January (2008) shows peak access with a total access of $17.7 \%$ (54 views), June (2009) with access rate of $73.17 \%$ (401 views) and August, 2010 with access rate of $7.86 \%$ (24). The highest mean score is seen over the months of January, September and May amounting to $11 ; 9.67 \& 7$ with a standard deviation of $16.52 ; 16.74 \& 10.44$ respectively. The months of June, July and August which were active months of violence in Kashmir had a mean score for article view as 2; 3 and 2.67 with a standard deviation of 3.46, 3.61 and 4.62. A total of 548 articles have been accessed in year 2009, 305 in 2008 and only 15 in 2010.On an average the lowest usage is witnessed in the year 2010 followed by 2008 and 2009 respectively. It is evident that a mean score of $25.42,45.7 \& 1.250$ and standard deviation of $15.46,113.3$ \& 3.441 for article view is scattered over the years 2008, 2009 and 2010. A minimum and maximum of 3 and 54 article views are seen in 2008 and for the years 2009 and 2010, the minimum and maximum article views amount to 0 and 401; and 0 and 12 respectively. The highest disturbance witnessed in the year 2010 followed by 2008 clearly reflects that 
conflict and disturbance have an adverse effect on the e-resource usage, an important dimension of education in a conflict zone like Kashmir. It is evident that 2010 among all the three years shows the lowest usage pattern. Kashmir witnessed the highest political unrest in 2010 among the three years and the highest number of strikes and curfews were prevalent in 2010, which affected the e- resource usage to a greater extent.

Table I. Article View

\begin{tabular}{lcrrrrr}
\hline \multirow{2}{*}{ Month } & \multicolumn{2}{c}{2008} & \multicolumn{2}{c}{2009} & \multicolumn{2}{c}{2010} \\
\cline { 2 - 7 } & Article & \multicolumn{1}{c}{$\%$} & Article & \multicolumn{1}{c}{$\%$} & Article & \multicolumn{1}{c}{$\%$} \\
\hline Jan & 54 & 17.7 & 0 & 0 & 0 & 0 \\
Feb & 39 & 12.78 & 0 & 0 & 0 & 0 \\
Mar & 38 & 12.45 & 4 & 0.72 & 0 & 0 \\
Apr & 35 & 11.47 & 0 & 0 & 1 & 6.66 \\
May & 33 & 10.81 & 1 & 0.18 & 0 & 0 \\
June & 26 & 8.52 & 401 & 73.17 & 2 & 13.33 \\
July & 26 & 8.52 & 0 & 0 & 0 & 0 \\
Aug & 24 & 7.86 & 42 & 7.66 & 12 & 80 \\
Sep & 10 & 3.27 & 29 & 5.29 & 0 & 0 \\
Oct & 10 & 3.27 & 0 & 0 & 0 & 0 \\
Nov & 7 & 2.29 & 46 & 8.39 & 0 & 0 \\
Dec & 3 & 0.98 & 25 & 4.56 & 0 & 0 \\
\hline Total & $\mathbf{3 0 5}$ & $\mathbf{1 0 0}$ & $\mathbf{5 4 8}$ & $\mathbf{1 0 0}$ & $\mathbf{1 5}$ & $\mathbf{1 0 0}$ \\
\hline
\end{tabular}

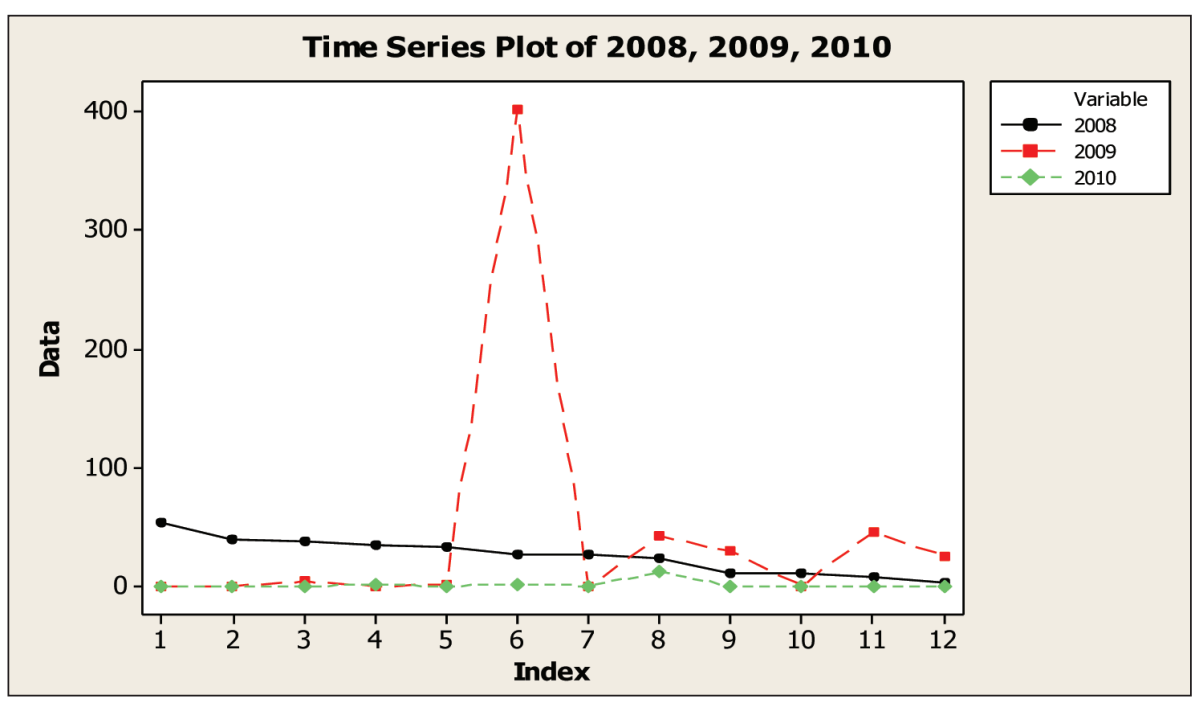

Figure 1. Article Views (2008-2010) 


\section{Searches Conducted}

A total of 130 searches were conducted during the study period ( 3 years) which is indicative of a very small number. 77 searches were performed in 2008; 45 in 2009 \& only 8 in 2010 (Table II, Figure 2). It is again evident that the year 2010 witnessed meager search conduction, which is again an indicative that the disturbance impediments the e-resource usage. It is evident that a mean of $6.42,3.75 \& 0.667$ and standard deviation of $9.14,8.64 \& 1.775$ is seen for the years 2008,2009 and 2010 respectively. A minimum of 0 searches have been conducted over all the three years while as a maximum of 29 , 30 and 6 searches are seen over the years 2008, 2009 and 2010.

Visualizing the monthly search conduction pattern, January again leads the list with a mean search conduction rate of 29 with a standard deviation of 31.8 .

Table II. Searches Conducted

\begin{tabular}{lrrrrrrrr}
\hline \multirow{2}{*}{ Month } & \multicolumn{7}{c}{ Year } \\
\cline { 2 - 9 } & $\mathbf{2 0 0 8}$ & $\%$ & $\mathbf{2 0 0 9}$ & $\%$ & $\mathbf{2 0 1 0}$ & $\%$ & Total & \multicolumn{1}{c}{$\%$} \\
\hline Jan & 3 & 3.89 & 30 & 66.66 & 0 & 0 & 33 & 25.38 \\
Feb & 0 & 0 & 2 & 4.44 & 0 & 0 & 2 & 1.53 \\
Mar & 0 & 0 & 6 & 13.33 & 0 & 0 & 6 & 4.61 \\
Apr & 3 & 3.89 & 0 & 0 & 0 & 0 & 3 & 2.3 \\
May & 19 & 24.67 & 0 & 0 & 2 & 25 & 21 & 16.15 \\
Jun & 0 & 0 & 0 & 0 & 6 & 75 & 6 & 4.61 \\
Jul & 2 & 2.59 & 7 & 15.55 & 0 & 0 & 9 & 6.92 \\
Aug & 8 & 10.38 & 0 & 0 & 0 & 0 & 8 & 6.15 \\
Sep & 29 & 37.66 & 0 & 0 & 0 & 0 & 29 & 22.3 \\
Oct & 0 & 0 & 0 & 0 & 0 & 0 & 0 & 0 \\
Nov & 2 & 2.59 & 0 & 0 & 0 & 0 & 2 & 1.53 \\
Dec & 11 & 14.28 & 0 & 0 & - & - & 11 & 8.46 \\
\hline Total & $\mathbf{7 7}$ & $\mathbf{1 0 0}$ & $\mathbf{4 5}$ & $\mathbf{1 0 0}$ & $\mathbf{8}$ & $\mathbf{1 0 0}$ & $\mathbf{1 3 0}$ & $\mathbf{1 0 0}$ \\
\hline
\end{tabular}

\section{Sessions Conducted}

Table III, (Figure 3) clarifies that total of 473 sessions were conducted over 3 years, among which 256 (54.12\%) were conducted in 2008, 202(42.7\%) in 2009 \& only $15(3.17 \%)$ in 2010. Highest rate of sessions were seen in the year 2008 (256) among all the 3 years while as 2010 witnessed a low session conduction because of the disturbance that prevailed the state more in 2010 . It is evident that a mean of $21.33 ; 16.83 \& 1.250$ sessions have been conducted over the years 2008, 2009 and 2010 with a standard deviation of $12.53 ; 21.69 \& 2.734$ respectively. A minimum of $3 ; 0$ and 0 and a maximum of $41 ; 64$ and 9 sessions have been conducted over the years 2008, 2009 and 2010. The mean sessions score over the months Jan, May, Mar, Sep, Jun, Jul, Apr, Nov, Feb, Oct, 


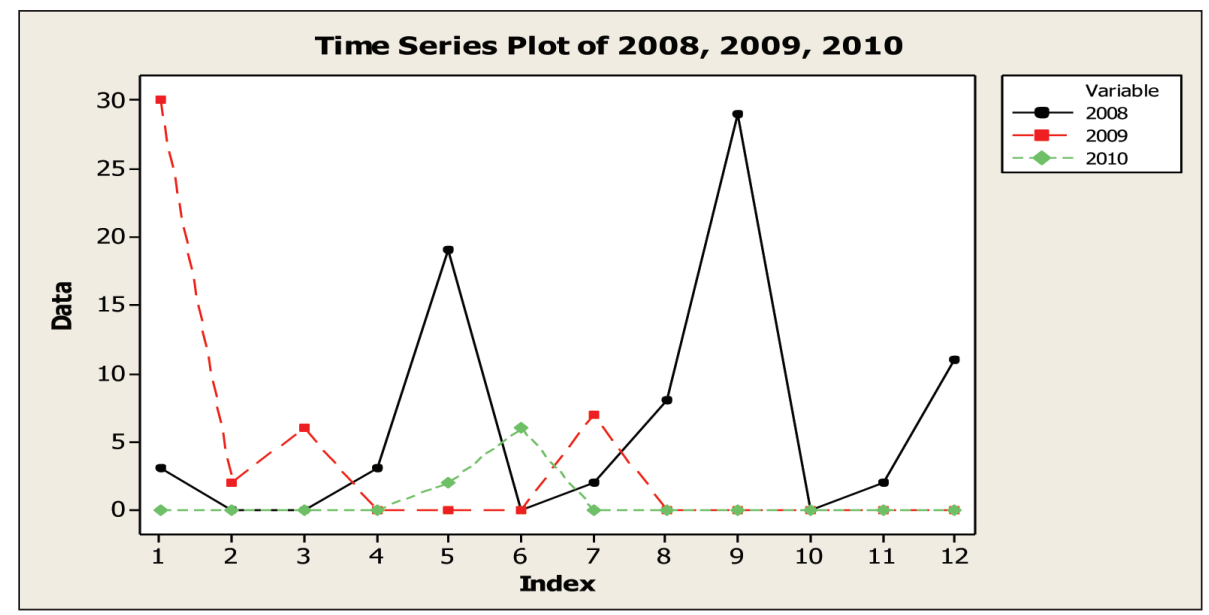

Figure 2. Searches Conducted

Dec, Aug amounts to 29, 19.33, 15.7, 14, 13, 12.7, 12.67, 10.3, 10, 8.67, 8.67 and 3.67 with a standard deviation of $31.8,13.8,21.4,23.4,19.2,17.8,15.53,17.9,14.8,15.01$, 15.01 and 6.35 .

Table III. Sessions Conducted

\begin{tabular}{|c|c|c|c|c|c|c|c|c|}
\hline \multirow{2}{*}{ Month } & \multicolumn{7}{|c|}{ Year } & \multirow[b]{2}{*}{$\%$} \\
\hline & 2008 & $\%$ & 2009 & $\%$ & 2010 & $\%$ & Total & \\
\hline Jan & 21 & 8.20 & 64 & 31.68 & 2 & 13.33 & 87 & 18.39 \\
\hline Feb & 3 & 1.17 & 27 & 13.36 & 0 & 0 & 30 & 6.34 \\
\hline Mar & 7 & 2.73 & 40 & 19.80 & 0 & 0 & 47 & 9.93 \\
\hline Apr & 8 & 3.12 & 30 & 14.85 & 0 & 0 & 38 & 8.03 \\
\hline May & 14 & 5.46 & 35 & 17.32 & 9 & 60 & 58 & 12.26 \\
\hline Jun & 35 & 13.67 & 0 & 0 & 4 & 26.66 & 39 & 8.24 \\
\hline Jul & 33 & 12.89 & 5 & 2.47 & 0 & 0 & 38 & 8.03 \\
\hline Aug & 11 & 4.29 & 0 & 0 & 0 & 0 & 11 & 2.32 \\
\hline Sep & 41 & 16.01 & 1 & 0.49 & 0 & 0 & 41 & 8.66 \\
\hline Oct & 26 & 10.15 & 0 & 0 & 0 & 0 & 27 & 5.70 \\
\hline Nov & 31 & 12.10 & 0 & 0 & 0 & 0 & 31 & 6.55 \\
\hline Dec & 26 & 10.15 & 0 & 0 & 0 & 0 & 26 & 5.49 \\
\hline Total & 256 & 100 & 202 & 100 & 15 & 100 & 473 & 100 \\
\hline
\end{tabular}




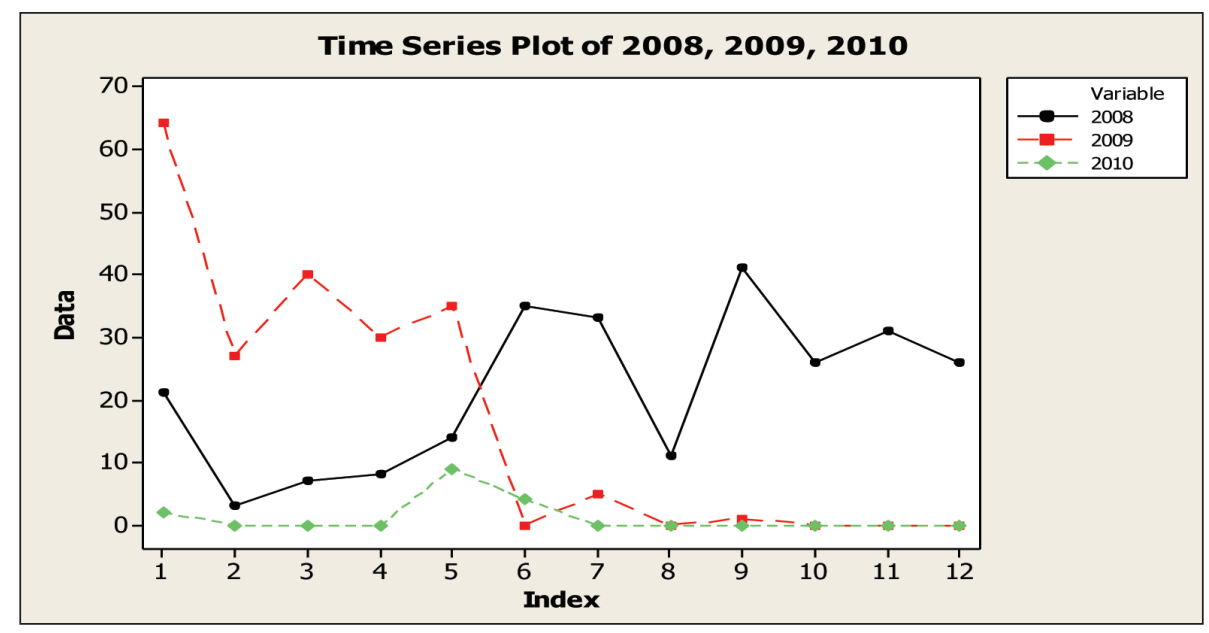

Figure 3. Sessions Conducted

\section{Discussion and Conclusion}

Log analysis can be used as one of the most important and influential monitoring tools for visualizing the academic efficiency in a politically disturbed area like Kashmir. Log analysis can in real sense act as a critical observer to relate conflict with education. The results of the study clearly reveal a declining pattern of use of e-resources in the times of conflict which is a reflective of negative impact of conflict on education. The internal crises of Kashmir, which are both more ancient and more profound, are the main reasons for disappearance of users from the electronic academic world. The political collapse which was witnessed in 2008, 2009 \& 2010 has proved that the indigenous problem of Kashmir has to be rethought which affects the educational sector of Kashmir to a greater extent as is evident from the study results. The lowest usage in the year 2010 supports the fact that political disturbance is the main cause of disappearance of users in the educational world. Kashmir witnessed a total educational failure in early 1990's also because of the start of unrest. Enhanced e-resource usage which is an indicator of academic development has been greatly hampered because of political precariousness in Kashmir.

Political regimes have conducted a silent war on the lives of people of Kashmir and also on education which is evident from the low e-resource usage portrayed through the study. Worsening political situation has even resulted in technological crisis in Kashmir which is again one of the determinants of low e-resource usage in Kashmir. The conservative led reforms in Kashmir have really hampered the educational to a greater extent. Kashmir is more in need of a true political solution which can help in building 
a better academic platform but unluckily Kashmiris are fatigued by the interminable "new beginnings" and deadened political initiatives and confidence building measures (CBMs) that accompany them (Chatterji, 2011).

A healthy academic sphere, which can be achieved only when peace prevails, will definitely affect the information seeking behavior of users in the electronic world and off-campus access is one of the best answers to it. Off-campus access should be promoted, which will breed and encourage the virtual movement in a disturbed area like Kashmir. Even in the times of conflict, the users can access the scholarly content remotely thus getting an opportunity also when the conditions don't allow them to visit their academic institutes.

Though the off campus access to e-resources started because of the results of 2008, 2009 and 2010 uprisings in the University of Kashmir, Kashmir is more in need of peace which in real sense can turn on the education to an accelerating platform.

So, the future of Kashmir and its academia really lie in a long lasting and a true solution that can turn the gloomy valley back in the paradise. Commenting upon the peace in Kashmir valley Kazi (2009) is of the view that if India and Pakistan wish to resolve Kashmir, they must not only commit to diplomatic dialogue and respect for Kashmiri identity and aspiration, they must also, simultaneously, delve in to their post and pre-colonial past in order to craft a better future.

So, log analysis as an analytical politico-educational tool can help in understanding the relation between political unrest and education to a greater extent. Such studies should be carried often and on in order to witness the effect of political disturbance on the academia in conflict zones. Kashmir is in need of a peace platform because they have become the victims of culture of vengeance for which they are nowhere to be blamed.

\section{Acknowledge}

The authors would like to thank Dr. Reyaz Rufai, Librarian at Central University of Kashmir for providing the usage statistics of Project Muse. Without his help it wouldn't have been possible to take up the study. He has also served as Librarian at University of Kashmir, Jammu and Kashmir. 


\section{References}

Aggarwal, J. C., \& Agrawal, S. P. (1995). Jammu and Kashmir at a glance. Modern history of Jammu and Kashmir: Including select documents and comprehensive reference bibliography covering all aspects of Jammu and Kashmir, 1844-1994. (p.2). New Delhi: Concept Pub. Co.

Bose, S. (1997). The challenge in Kashmir: Democracy, self-determination and a just peace. New Delhi: Sage.

Chatterji, A. P. (2011). The militarized zone. In Tariq Ali, Hilal Bhat, Arundhati Roy, Angana P. Chatterji \& Pankaj Mishra (Eds.). Kashmir: The case for freedom (p.121). New York, N.Y: Verso.

Colenso, P. (2005). Education and social cohesion: developing a framework for education sector reform in Sri Lanka. Compare, 35(4), 411-428. doi:10.1080/03057920500331470

Covey, D.T. (2002). Usability and Usability Assessment: Library Practices and Concerns, Council on Library and Information Resources. Washington, January 2002. Retrieved from http://www.clir.org/pubs/reports/pub105/pub105.pdf.

Dehlvi, S. (2009). Interview. Conveyor, 1(3), p. 48.

Inden, R. (2008). Kashmir as paradise on earth. A. Rao, T.N. Madan (Eds.), In The valley of Kashmir: The making and unmaking of a composite culture? (p.523). New Delhi: Manohar Publishers.

Jaisingh, H. (1998). Signals from the valley: Kalashnikovs in paradise. S. Kaul. \& O. Kachru. (Eds.), In Jammu, Kashmir, Ladakh: Ringside views (p.14). New Delhi: SehyogPrakashan.

Kazi, S. (2009). Kashmir, India, the nation-state and South Asia. Conveyor, 1(3), p.24.

Mohan, S. (2000). Kashmir, is there a solution? (p.1).Delhi: Indian Publishers Distributors

Navlakha, G. (2009). Anatomy of status quo. Conveyor, 1(4), p.34.

Nicholas, D., Huntington, P., Lievesley, N., \& Withey, R. (1999). Cracking the code: web log analysis. Online Information Review, 23(5), 263-269. doi:10.1108/14684529910334074

Nicholas, D., Huntington, P., \& Watkinson, A. (2005). Scholarly journal usage: the results of deep log analysis. Journal of Documentation, 61(2), 246-280. doi:10.1108/00220410510585214

Paulson,J., \& Rappleye, J. (2007). Education and conflict: essay review. International Journal of Educational Development, 27(3), 340-347. doi:10.1016/j.ijedudev.2006.10.010

Peters, T.A. (1993). The history and development of transaction log analysis. Library Hi Tech,11(2), 41-66.doi:10.1108/eb047884

Roy, A. (2011). Seditious Nehru. Tariq Ali, Hilal Bhatt, Angana. P.Chatterji, HabbahKhatun, Pankaj Mishra \& Arundhati Roy (Eds.), In Kashmir : the case for freedom (p.125). New York, N.Y: Verso

Seitz, K. (2004 a). Education and conflict: the role of education in the creation, prevention and resolution of societal crises - consequences for development cooperation (pp. 8-9). Germany: German Technical Cooperation/Deutsche Gessellschaft fur TechnischeZusammenarbeit (GTZ). Retrieved from http://reliefweb.int/sites/reliefweb.int/files/resources/1F610940FB2A5 1B749256FFE001BD784-EDandConflict-GTZ.pdf 
Seitz, K. (2004 b). Education and conflict: the role of education in the creation, prevention and resolution of societal crises-consequences for development cooperation (p. 21). Germany: German Technical Cooperation/Deutsche Gessellschaft fur TechnischeZusammenarbeit (GTZ). Retrieved from http://reliefweb.int/sites/reliefweb.int/files/resources/1F610940FB2A5 1B749256FFE001BD784-EDandConflict-GTZ.pdf

Stewart, F. (2003). Conflict and the millennium development goals. Journal of Human Development, 4(3), 325-351. doi:10.1080/1464988032000125737

Sudan, F. K. (2010). Social and economic costs of armed conflicts on children: Evidence from displaced camps in Jammu and Kashmir, India. Oxford, United Kingdom: Households in Conflict Network, February 1. Retrieved from http://www.hicn.org/FifthWorkshop_Sudan.pdf

Tomlinson, K., \& Benefield, P. (2005 a). Education and conflict: Research and research possibilities. National Foundation for Educational Research (pp.12-13). Retrieved from

http://www.nfer.ac.uk/research-areas/pims-data/outlines/education-and-conflict-a-scopingstudy.cfm

Tomlinson, K., \& Benefield, P. (2005 b). Education and conflict: research and research possibilities. National Foundation for Educational Research (p.341).Retrieved from http://www.nfer.ac.uk/ research-areas/pims-data/outlines/education-and-conflict-a-scoping-study.cfm

Udell, J. (1996). Damn lies. Byte. February, Retrieved from www.byte.com/art/9602/sec12/art1.htm

UNESCO Institute for Statistics. (2010). The hidden crisis: Armed conflict and education. Education for all: Global monitoring report 2011. Montreal, Canada: UNESCO. Retrieved from http:// unesdoc.unesco.org/images/0019/001913/191304e.pdf

Watkins, K. (2000). The Oxfam Education Report. Dorset, England: Oxfam. 